\title{
Zen and the Body: A Postmodern Ascetic? Bodily Awakening in the Zen Memoirs of Shozan Jack Haubner
}

\author{
Ben Van Overmeire
}

Citation: Van Overmeire, Ben. 2021. Zen and the Body: A Postmodern Ascetic? Bodily Awakening in the Zen Memoirs of Shozan Jack Haubner Religions 12: 122. https://doi.org/ $10.3390 /$ rel12020122

Academic Editor: Brooke Schedneck

Received: 29 January 2021

Accepted: 12 February 2021

Published: 15 February 2021

Publisher's Note: MDPI stays neutral with regard to jurisdictional claims in published maps and institutional affiliations.

Copyright: (C) 2021 by the author. Licensee MDPI, Basel, Switzerland. This article is an open access article distributed under the terms and conditions of the Creative Commons Attribution (CC BY) license (https:// creativecommons.org/licenses/by/ $4.0 /)$
Division of Arts and Humanities, Duke Kunshan University, Kunshan 215316, China; ben.van.overmeire@dukekunshan.edu.cn

Abstract: In this article, I examine two memoirs by the American Zen Buddhist author Shozan Jack Haubner. Within the contemporary genre of American Zen autobiographical literature, Haubner's books are special in that they explore Zen awakening as driven by the body. Penetration, pregnancy and sickness are the main figures Haubner uses to show how his autobiographical protagonist accesses the Buddhist truth of no-self. Though these books can thus be said to map an ascetic quest for the erasure of individuality, this quest proceeds not through the imposition of will onto the body, but the body imposing its will on the self. Because this is somewhat different from how the ascetic self is usually theorized, I propose to call Haubner's main character a "postmodern ascetic".

Keywords: Zen Buddhism; autobiography; body; queer studies; asceticism; Charles Taylor; postmodernism

\section{Introduction: "Jumping the Wall"}

Among the many memoirs describing autobiographical experiences in contemporary American Zen contexts, Shozan Jack Haubner's work stands out in several ways. Compared to most examples of the genre, which often connect the author's life experiences to Zen Buddhist teachings, Haubner's two published memoirs feature a significant amount of sex and defecation. The purpose of including these aspects of the body in the books fits Haubner's quest to destroy, as he writes in his first book, Zen Confidential, the popularculture vision of Zen as "a kind of balmy, glassy-eyed minimalist aesthetic and little more" (Haubner 2013, p. 4). He finds that "too many Buddhist books focus on the lotus of enlightenment, as it were, and skip the muck from which it arises" (Haubner 2013, p. 8) This leads to the delusion that Zen monks just sit blissfully in enlightenment all day. To combat the aestheticized image of Zen, Haubner, who is a former monk in the Rinzai Zen tradition of Joshu Sasaki, consciously turns towards the "muck." Apart from feces and semen, this includes a detailed account, in his second memoir Single White Monk, of the fallout of the sexual scandal that haunted the last years of Sasaki, who was accused of having sexually abused hundreds of his female students (Vitello 2017). For Haubner, the scandal led to an agonizing look at his own responsibility for Sasaki's behavior. Ultimately, Haubner understands the darker aspects of himself and his teacher within a framework of nonduality, where light is intertwined with dark.

But who is Shozan Jack Haubner? This pen name refers to a former Zen priest (Osho) in Sasaki's lineage, who trained at Rinzai-ji Zen Center in Los Angeles. He is a white, straight man in his mid-forties, who grew up in a Midwestern Catholic family, with a father whose company makes rifle barrels. ${ }^{1}$ In early adulthood he drifted to Los Angeles, where he tried to make a career writing for Hollywood, without much success. In LA, he met someone called his "mentor," who introduced him to Zen practice and to Sasaki. At Rinzai-ji, Haubner made the acquaintance of singer-songwriter Leonard Cohen, who

1 The estimate of Haubner's age here is based on Haubner's autobiographical novels. In Single White Monk, the narrator declares he is forty years old (Haubner 2017, p. 11) 
would go on to write the preface to his first book. Haubner quickly became one of Sasaki's closest aides, but left the Zen Center and his position there after Sasaki died. According to his Twitter account description, he is currently "at large," and also "available for parties," while a recent post on Medium mentions that he's currently in Europe (Haubner 2020).

At least since Peter Matthiessen's Nine-headed Dragon Rivier (1985), there has been a tendency in American Zen autobiographical literature to locate at least part of the responsibility for sexual abuse on the students themselves, who come to Zen practice with too idealist notions of who the master is. Matthiessen's book phrased this problem in a way strikingly similar to Haubner: Matthiessen's generation imagined Zen as a "clear oasis where life could be kept pure, spare, and simple, as in the Buddhist image of the white lotus rising from the muddy water" (Matthiessen 1985, p. 63). In Natalie Goldberg's account of her discovery of her teacher's sexual relationships during the 1990s, she describes that she and others dreamed of "something pure, untouched, celestial," leading people to want to minimize her teacher's shadow side: "We were all dedicated to our dream of him" (Goldberg 2004, pp. 133, 144). Finally, Gesshin Claire Greenwood came to Japan in the early years of the new millennium "enthralled with a dream of Zen, a dream of enlightenment," but discovers that things are much more complicated, and that her teacher, with whom she falls in love and who loves her back, is more human than divine (Greenwood 2018, p. 25).

The difference between Haubner's two memoirs and most other Zen autobiographical literature is that Haubner's focus is as much on "the muck" of American Zen as its "lotus." Whereas Matthiessen and Greenwood merely hint at the pain caused by the behavior of their teachers, Haubner discusses the problematic aspects of Sasaki quite explicitly. Though Goldberg does describe near-sexual encounters between Katagiri and herself, and also mentions accidentally interrupting sex between him and a student, her descriptions are not as directly physical as Haubner's. As I show in this article, Haubner's emphasis on the body and its"muck" has a distinct function: it draws attention to the body as the main driver of spiritual awakening, understood as gaining a nondual perspective on reality.

A typical example of how this principle operates is "Jumping the Wall," one of the chapters of Single White Monk: Tales of Death, Failure, and Bad Sex (Although Not Necessarily in that Order), the second of the two memoirs that will be discussed here. As Haubner tells his readers, "jumping the wall" is

an ancient, unspoken tradition in Zen. After kaichin, or closing gong, restless young monks the world over sneak out to low hanging branches and struggle their way up and over the monastery wall to the booze, breasts, and bongos beyond. (Haubner 2017, p. 49)

Smoking a joint, Jack ${ }^{2}$ reflects that "it's often the violation of rules that triggers the greatest liberation" (Haubner 2017, p. 48). In accordance with this principle, he sneaks out to visit a sex worker, driven by his body's desire: "my dick is thinking for me, and doing a pretty spotty job of it" (Haubner 2017, p. 50). Jack's sex drive is then likened to the Santa Ana winds that blow against the temple, tearing it apart bit by bit" (Haubner 2017, p. 58). It is hard to resist these winds, a problem Haubner, using a Zen metaphor, summarizes as follows:

You have to do the right thing, only you're not built to: such is the koan of living in a body - male in my case. My inner Ethel [Jack's conscience] is not the answer. Nor is an erotic masseuse. But what the answer is, I don't know. (Haubner 2017, p. 63)

This understanding of koan, riddles that are very important within the Rinzai Zen of Sasaki, is typical of Haubner's work as a whole. Instead of focusing on personal volition as important, it is Jack's body that forces him towards spiritual insights, particularly the

2 I will refer to the autobiographical protagonist of the novel as "Jack," and reserve Haubner for the autobiographical narrator. This acts as a reminder that "Jack" is always a construction, a representation of the self, and we should beware of uncritically accepting Jack as an accurate representation of the life of "Haubner." 
body's excretions and desires. This is what "jumping the wall" means: it is both the pursuit of (sexual) enjoyment and the transgression of dualist categories more generally: Haubner's work shows, again and again, that sacred and profane are connected, and that "walls" only exist in our minds.

In understanding the body as the driving force in his spiritual quest for nondual insight, Haubner's memoirs describe an unwilling quest to undermine what Charles Taylor has called the "buffered self," a modern narrative that sees the "self" as completely separate from its environment (Taylor 2007). In the narrative of the buffered self, the body is nothing more than a flesh container for the Cartesian ego, which controls it like a tool. Though Jack tries to maintain his bufferedness, ultimately his body forces him to see he is what Taylor would call "porous" to outside influences.

If Haubner's books then portray a body that forces the self to realize its porosity towards the rest of the world, Jack cannot be fully understood within the comparative framework Ariel Glucklich and Gavin Flood have elaborated on asceticism (Glucklich 2003; Flood 2005). For both these scholars, ascetics impose their will on the body, disciplining it to conform to a traditional pattern. The purpose of this discipline is to erase individuality: the body stands in for the whole individual, and in making the body conform, often by hurting it or depriving it of necessities, ascetics see themselves as also disciplining their soul, moving it from something separate and individual towards a nondual unity with the divine. When an individual subjects his body to the discipline of tradition, the idea is to will away the will, a paradox that many religious traditions, Zen not least among them, have pointed out.

Both Flood and Glucklich see the modern era as hostile to asceticism. For Flood, the modern quest for authenticity is in contradiction with disciplining the self in accordance with tradition. For Glucklich, whose book focuses on religious understandings of pain, the advent of modern medicine and anaesthesia have made pain into something to be avoided rather than embraced. Unlike, for example, medieval mystics who hurt themselves to destroy their personhood and become one with God, moderns see pain as an unwanted interruption of cherished individuality, a meaningless inconvenience that modern medicine has not yet solved.

While Flood suggests that the ascetic self, having faded with modernity's rejection of tradition, returns during postmodernity, it is not clear from his discussion what this self looks like (Flood 2005, pp. 235-57). Haubner's books suggest that this postmodern ascetic is in some ways the reverse of Flood's: Jack does not impose his will on his body, but his body imposes its will on him. One way it does so is through pain, but more important than pain is Jack's sexual desire. Despite his best efforts to keep himself buffered from his environment, Jack again and again sees his body penetrated by that environment. His failure to maintain his phallic identity eventually leads to him gaining insights in the nondual nature of reality.

I examine how Jack's body forces him towards insight in the following manner. First, I describe how projection works in Haubner's books. An important psychoanalytical mechanism in Zen life narratives more generally, in Haubner's work projection explains everything that happens to Jack as the result of conflicts within Jack's self. Anything that happens to Jack can be a means of realizing that the boundaries between the self and others are illusionary. Then, I summarize how Jack was raised to believe the opposite. Jack's father has taught him to be self-reliant, and to close himself off from others. The penetration of this phallic self, and thus the destruction of the illusion of bufferedness, takes several forms. Jack sees himself becoming anally penetrated on film, his sexual desire produces visions of women showing him his complicity in the sexual scandal, a terrible disease makes Jack surrender his body to "demons"; and an Ayahuasca session exposes that Jack needs a connection to another person to flourish spiritually. I conclude by returning to Flood and Glucklich's idea of the ascetic self, and bringing these ideas in conversation with work on the postmodern body. 


\section{2. "The One Thing We Never Do Is Allow Them to Be Human:" The Projection Mechanism}

Before exploring Jack's body, we need to understand how projection works in Haubner's books. This concept, drawn from psychoanalysis, appears in numerous contemporary Zen memoirs. ${ }^{3}$ Like these other authors, Haubner uses projection as a way to understand why Zen communities have been so permissive of their teachers' aberrant behavior:

We project so much onto our teachers, all our hopes and dreams, and when they fail to live up to our expectations we project all our fears and demons onto them. The one thing we never do is allow them to be human. (Haubner 2017, p. 167)

Projection here means that individual desires can deeply influence how the teacher is seen. This causes students to then disregard actions that do not correspond to their imagined ideal. When the teacher's actions, however, become so extreme that maintaining the ideal becomes impossible, the teacher comes to represent all that is bad in the world. Neither extreme adequately captures the teacher's fragile and ambiguous humanity, which cannot be captured by a dualist terminology like good/bad.

One of the stakes of Haubner's Single White Monk is recovering this complexity. To do so, he uses projection as an organizing narrative principle. As he writes in the introduction to Single White Monk, any character in the book is a manifestation of himself (not just the teacher). Writing thus functions through projection, and seeing through projection means seeing through the narrative construction of selfhood:

In writing, you take a thesis and get it going, or you conjure a protagonist and put her on a path. Then you throw up an obstacle-an antithesis or villain. Through their relationship (war is weak intimacy, as the saying goes) an answer is born, a synthesis. This synthesis is the manifestation of True Love, the marriage of opposing forces. In these pages, I am both protagonist and antagonist. I like to be the center of attention. Put another way, I'm self-centered, a self that I am trying to kill off in every scene. (Haubner 2017, p. 6)

For Haubner then, any single person in his memoirs is a manifestation of the "self," taking the roles of both main character and adversary. In the course of the narrative, both these roles merge back into the self, with Haubner here using the language of his teacher Sasaki ("True Love") to enunciate a view of nonduality, a question of how everything, good and evil, can co-exist in the same world (Haubner 2017, p. 8). Accordingly, the narrative progression of his books coincides with the Buddhist quest for insight in the doctrine of no-self: the self has to be destroyed because it is an illusion that is harmful.

\section{3. "My Pecker:" A Failed Phallic Education}

If Haubner's approach to projection as narrative is rather unique, so is his understanding of agency. Unlike most contemporary American Zen authors, Haubner does not portray Jack's spiritual quest as something he is in charge of. Rather, his body pushes him, again and again, to understand things that his conscious ego wants to remain unaware of. One of these truths is porousness: as I will explain now, Jack is raised to be a phallic person, led to believe himself independent of anything and anyone, to be something that penetrates but is not penetrated itself. This phallicness is linked to his masculine identity, and Jack's understanding that his self is in fact porous, as we will see in the next sections, is therefore connected to his discovery of his inner femininity.

In Zen Confidential, Haubner gives a detailed account of his upbringing, particularly his relationship to his father and how this relationship shaped his sexual identity. In a chapter titled "A Zen Zealot Comes Home," Haubner describes Jack's conflicted feelings about his father's job: Jack Sr. has built a very successful business producing custom-made rifle barrels. Due to a work accident, he lost

\footnotetext{
3 See, for example the memoirs by Goldberg, Greenwood, and Grace Schireson (Goldberg 2004; Greenwood 2018; Schireson 2019). Apart from these authors, Ann Gleig has documented how the language of psychotherapy is a key element in American Buddhist modernity and postmodernity (Gleig 2019, pp. 84-110).
} 
the top half of his right index finger. (Yes, his trigger finger). After several medical mishaps, that digit is now missing. In its place is a curiously malformed combination of flesh and scar tissue that bears a striking resemblance to another typically less visible part of the male anatomy. "My pecker," he calls it, waving the stubby appendage up and down in a suggestive manner. (Haubner 2013, p. 99)

Through another common utterance of his father, "We Germans think with our hands," we can easily associate Jack's father's mangled "pecker" hand with his work producing phallic instruments of death. As Haubner tells his reader, the worldview of Jack Sr. is conservative and individualist, and he does not accept anything from anyone. Within his worldview of the phallus, one shoots but does not receive, one penetrates but is not penetrated. For example, the very idea of begging for food, a Buddhist practice, is antithetical to Jack's father (Haubner 2013, p. 100). Instead, one takes what one can get, through violent means if necessary. Such violence Haubner sees as being passed on from man to man in his family, in the physical violence his father inflicted upon Jack as a child (Haubner 2013, p. 102). One of the other chapters about Jack Sr. is titled "son of a gun," emphasizing this connection between fatherly authority and phallic violence. Psychologically though, Jack Sr. is completely isolated, like the basement shelter he built and keeps stocked with provisions for the time when "the shit hits the fan" (Haubner 2013, p. 100). Jack's father is thus a typical example of Taylor's buffered self: he believes that the self is ultimately independent of its environment.

But Haubner's physical make-up prevents him from successfully becoming a successor to his father. In Single White Monk, he writes: "My first two Zen teachers were, in this order, failure and my father. And the very first thing I failed at was being physically big" (Haubner 2017, p. 16). In a chapter titled "Dirt Monkey," Haubner describes his lack of muscles and physical aptitude when he was a teenager, and how it contrasted with his father's success as a small business owner who made money doing what he loved. Large sections of Zen Confidential describe Jack's attempts to make money writing movie scripts and finding love in Hollywood, all of which fail miserably. But the greatest failure in these books is Jack's inability to recognize the aberrant behavior of his teacher, even hiding it in Zen Confidential, which was published just when the scandal become public. In Single White Monk, he writes about his first book: "I came close to showing his [Sasaki's] dark side in the final chapter, but then I balked" (Haubner 2017, p. 136). As long as he tries to be a phallic man like his father, Jack is unable to embrace both the dark and light in himself and in his teacher.

\section{4. "You Gotta Learn to Bottom:" Queerness, Femininity, and Liminality}

That Jack Sr.'s attitude towards life as something separate to be dominated and controlled has affected his son is most forcefully diagnosed by Jack's spiritual "mentor." This is an otherwise nameless gay man who introduces Jack to Zen meditation. When Jack complains to him about Sasaki's behavior, this mentor suggests a solution in terms that combine the spiritual and sexual:

"You gotta learn to bottom," he told me. "Come again?" "You're an angry young straight white dude, man. You think the world belongs to you, and so you just try and ram your way through it, grabbing whatever you want. You have to learn to take a dick. Otherwise, you'll become a dick." He saw the look on my face. "What I mean is, you gotta open your heart and let the big bad world in." To his horror, before we went out the next three times I put on a black dress, wig, and heels and transformed myself into ... what, I still don't know. (Haubner 2017, p. 167)

Here, Jack's phallic identity is connected with Taylor's buffered self. Jack is unable to relate to others because he does not open up to them. Instead, he wants to possess everything, and in the process he ignores the "bad" things he himself and others around him are doing. The importance of this passage and its particular metaphor for Haubner are indicated by the fact that it reads like a rewrite from Zen Confidential. When the same mentor is teaching Jack how to do sitting meditation, he tells Jack: "'You look like you're trying to move your 
bowels;' he said. 'Straight guys always have trouble with this. You have to 'bottom' for the world around you. Let it in baby! Get knocked up!'” (Haubner 2013, p. 148). Instead of just emitting bodily fluids into the world, Jack has to learn how to accept them. Both in Single White Monk and in Confidential, the type of sexuality that receives is connected with a queer and feminine gender identity, with "bottoming" referring to anal intercourse, but the expression "get knocked up" referring to becoming pregnant.

The connection between the body, sexuality, and insight are already present in the introduction to Single White Monk. After the aforementioned section where Haubner describes narrative as a way of "killing off" the self, he provides another important metaphor to understand his work: "In every chapter I'm trying to shed skin, get down to the bone, let you contemplate death in its many forms with me, like the Vedantic sadhus who meditate in charnel grounds beside smoldering corpses" (Haubner 2017, p. 7). The most striking element of this passage is Haubner's comparison of writing with corpse contemplation. This famous Buddhist practice, traceable to the earliest sutras, entails visiting charnel grounds to meditatively observe the decomposition process of human bodies. As Liz Wilson has shown, however, not all charnel bodies were made equal: it was attractive female bodies that were specifically recommended for this practice, with the purpose of piercing male sexual fantasies (Wilson 1996). Yet we cannot definitively identify Haubner with the (implicitly male) "sadhu" observer: if we read this statement closely, we can see that the grammar is tantalizingly ambiguous. The phrase "let you contemplate death in its many forms with me, like the Vedantic sadhus who meditate in charnel grounds beside smoldering corpses" does not identify who is sadhu and corpse, and this is exactly the point. Haubner is both male sadhu and female corpse, and so, too, should they be willing to look inside, is his audience. Because Haubner's work aims at the destruction of such comfortable identities as male/female; alive/dead; good/evil.

In a long chapter of Confidential titled "Glorious Openings in the Windy City," Haubner shows how this spiritual progress through queer and feminine sexuality happens entirely beyond the conscious control of Jack. In that chapter. Jack encounters himself in a gay porn movie. In this movie, a person who looks exactly like Jack has sex with a multitude of men. This double, called Daniel Reed, looks like Jack in every way, and therefore Jack finds himself unable to convince his mentor, who shows the movie to him, that he's not in fact Daniel. Completely disoriented, Jack gains deeper insight into the Buddhist truth of non-self:

It's one thing to get your philosophical rocks off while half drunk in a cool LA gay bar, mocking your childhood. It's quite another to finally realize, with your eyes, mind, and heart, that your most cherished opinions about yourself are ultimately flaccid and worthless, like Daniel Reed at the end of a day's shoot. There was absolutely no idea of myself, great or small, that couldn't be toppled with enough raw evidence: I discovered this bit of truth as raw evidence of my career in celluloid sodomy groaned on the TV before me. (Haubner 2013, p. 156)

Like the "vedantic sadhus" observing decomposing female corpses in the graveyard, Jack here gains insight into the Buddhist doctrine of no-self. He gains this insight unwillingly, because he sees what he thinks of as his own body, the "raw evidence" of the quotation, in situations that are completely dissociated from narratives he has spun about who he himself "is." This breakdown of the ego, of the self that exists buffered from environmental influences, is further shown by Jack's ultimate admission ("Fuck it, . . he's me") that Reed is he himself, even though Jack and Daniel Reed are two different people (Haubner 2013, p. 156). Jack's mentor, however, then rejects this admission, saying that Haubner's feet are much "cuter" than Daniel Reed's (Haubner 2013, p. 157). In "Glorious Openings in the Windy City" Jack's body forces him to realize that his ideas of selfhood mean nothing.

Jack's body also forces him to face his feminine side. This femininity is called his "true woman," a reference to a classic Zen text. As we saw above, in response to his mentor's injunction to "bottom," Jack crossdresses. When he then tells his mentor that he wants to "find my voice as a woman," he is told: "You need to learn to listen. There's a true 
woman somewhere inside you, but you keep speaking over her" (Haubner 2017, p. 168). With the formulation "true woman" Haubner modifies a phrase mainly associated with the famous Zen master Linji Yixuan (died 866 CE), whose Japanese name, Rinzai Gigen, is also that of the Zen lineage Haubner studies within. In the opening section of the standard edition of the Record of Linji, a hagiographical text describing his speeches and actions, Linji talks about "the true person without rank" (wuwei zhenren 無位真人). According to Ruth Fuller Sasaki (no relation to Joshu Sasaki, Haubner's teacher), Linji adapted this term from the Zhuangzi's ideal "True Man," which in Buddhist works came to stand for enlightened beings (Sasaki 2009, p. 130). Linji's initial treatment of this honorific title is typically irreverent:

The master, taking the high seat in the hall, said, "On your lump of red flesh is a true man without rank who is always going in and out of the face of every one of you. Those who have not yet confirmed this, look, look!" A monk came forward and asked, "What about the true man without rank?" The master got down from his seat, seized the monk, and cried, "Speak, speak!" The monk faltered. Shoving him away, the master said, "The true man without rank-what kind of dried piece of shit is he!" Then he returned to his quarters. (Sasaki 2009, pp. 129-31)

One can see why this famous scatological passage would appeal to Haubner, who liberally uses excrement in his books as well. Linji here establishes that the "true man" is present within every person, if only we would see it. At the same time, the true man is not to be revered as higher than us. It is us, the Buddha-nature many Mahayana Buddhists (Zen is a Mahayana school) believe lies deep inside of us. Returning to Jack's interaction with his mentor, we can see that something similar is meant here: the "true woman" that the phallic Jack is "speaking over" can be identified with his true self, his nondual Buddha-nature.

Jack comes face to face with this true woman in the middle of the long chapter describing the aftermath of the sex scandal. Having informed us of his plan to masturbate while on a break caring for his disabled and sick teacher, he uses his laptop to search the internet for "real amateur ebony orgasm," and opens two links. The first link shows him a pornographic movie where a black woman has sex with a "balding red-faced maniac ... with a great and hateful concentration" (Haubner 2017, p. 156). The second link gives him access to a woman called Jazmin inviting paying customers to watch her masturbate. Disappointed, Jack closes the laptop and tries to masturbate while fantasizing, but he cannot summon a satisfactory image. Before he knows it, he falls asleep and comes face to face with a woman whose appearance is always different, but who is a constant in his dreams:

We spend hours melting into each other, whispering; very often she tells me something right before I wake up that I can never remember. And when I wake up I always feel incredible, not even loved, but like love itself, like the woman I need is inside of me. (Haubner 2017, p. 157)

From this phrasing, it is clear that this oneiric woman refers to the "true woman" the mentor mentioned earlier. But significantly, Jack is only able to speak to this woman when his conscious ego is not in control, when he is unconscious and not "speaking over her."

Appropriate to the Zen context she derives from, this "true woman" goes on to teach Jack about nonduality. Manifesting as a "Nigerian goddess," in correspondence with Jack's sexual desire for a black woman, she urges him to see clearly both Sasaki's aberrant behavior, his own complicity in it, and how such things also need to be understood in a nondual framework. First she tells him that "This Sangha is full of violent men. And you're one of the worst" (Haubner 2017, p. 158). To understand this, Jack needs to "Face [his] past," more particularly a traumatic incident in Atlanta, where Jack witnessed Sasaki sexually touching Lizzie, one of his assistants and one of Jack's ex-girlfriends (Haubner 2017, p. 162). Instead of berating Sasaki for his behavior though, Lizzie tells Jack that he's too uptight about how he sees Roshi. The reason he is "still stuck" spiritually, Jack is told, is because "you draw all these lines in the sand around your relationship 
with him [Sasaki]" (Haubner 2017, p. 164). As a Nigerian goddess, the true woman thus points to an understanding of nonduality that is directly linked to the body and sexuality: her appearance is conditioned by Jack's sexual fantasies, and she uses the sexual scandal surrounding Sasaki, including repressed memories of Sasaki abusing Lizzie, as a way of pushing Jack beyond the bufferedness of his phallic self.

The end of the chapter emphasizes this entanglement of body, sexuality and spirituality. Dead-tired, Jack opens his laptop again, looking for "a hit" of Sasaki's wisdom contained in a video recording. But as Sasaki's words flow through the speakers of his computer, they get mixed with sexual moaning, leading Jack to believe that he's going crazy. Like with oneiric appearance of the dream woman, he believes that "there's someone in the room with me" (Haubner 2017, p. 169). He then discovers that the moaning is in fact coming from Jazmin, whose webcam link had remained open in the background. The audiotracks of both Sasaki and Jazmin merge:

Completely dissolve yourself.

I need 100 percent.

Oh year, baby, I need it, give it to me.

Your ego too big!

It's so big.

Put it in me. (Haubner 2017, p. 170)

Again, Zen teaching is combined with sexuality, and the teaching happens beyond Jack's conscious intentions. He concludes: “Love and lust. I can't tell them apart. My koan still. I shut the laptop lid". (Haubner 2017, p. 170)

\section{5. “My Body Was Pregnant with Its Antithesis:" Pregnancy and Disease}

As was already clear from the "get knocked up" injunction, pregnancy is also a prominent metaphor for nondual awakening in these memoirs. Haubner repeatedly pays homage to the immense role female Zen Buddhists have played and continue to play in the tradition. In Zen Confidential, Haubner writes that "Zen has a bad reputation as an overly patriarchal tradition" continuing to say that "women actually manifest the complete fusing of self and other in their pregnant wombs, which are the physical embodiment of our 'circle of awareness' expanding to encompass, ultimately, all things" (Haubner 2013, pp. 94-95). Jack's quest to step over the aforementioned "lines in the sand" that have defined him as a buffered, phallic heterosexual also means that he has to become figuratively pregnant. Jack again does not intend for this to happen, but his body leads the way.

In a chapter called "Expiration Date," Haubner again imagines the female body in relation to the transcendence of opposites, in this case birth and death. The topic of the chapter is an episode of what was medically described as an attack of pancreatitis, but which felt like "my body was pregnant with its antithesis, as though a howling death baby was clawing its way out of me" (Haubner 2017, p. 81). Notice that in encountering what he feels like is the moment of death, Jack's body becomes "pregnant." This is a key motif in the chapter, because the pancreatitis turns Jack into a "patient," someone who has to accept everything, someone who receives and who has lost the phallic power he once thought to possess. It is telling that the only mention of Jack's genitals in the chapter are of it being manipulated by others, first the monastery cat (clawing at it while Jack, throwing up, hangs over the toilet) and then a nurse in the hospital. Jack's neighbor in the emergency ward is a woman about to give birth, a memory he afterwards imagines as demonstrating that life and death are intimately connected: "I want to say that we both recognized that the birth in her and the death in me were two sides of the very same thing" (Haubner 2017, p. 92). By becoming sick, Jack's body again teaches him that all things are connected.

4 Of course, Haubner's own view of femininity as grounded in motherhood is equally patriarchal and androcentric, connecting women to the labor of bearing children, a connection that has been so elaborately criticized as to need little elaboration here. 
Similar to the suggestion of "bottoming reality," the eventual cure to Jack's disease consists of giving up control and accepting everything that happens. After being released from the hospital, Jack still does not feel much better. He is only cured by the insight a Catholic Priest in his hometown gives him, namely that the disease is caused by his religious life, which causes his demons to come out. Instead of fighting these demons, the priest tells him to "let them slay you" (Haubner 2017, p. 90). For the first time in months, Jack sits in meditation, and after recognizing that he has to continue living, he has a moment of insight. Afterwards, instead of the pain in his abdomen, he feels a "twitch of recognition, like the first kick of life in a mother's womb, the pulse that is equally self and other" (Haubner 2017, p. 92). Again, by accessing the femininity inside of him, Jack sees that the boundaries between himself and others are arbitrary.

It is not just Jack who becomes a patient. The scandal becomes public just as Sasaki, over a hundred years old, is recovering a from stroke and falls into a pneumonia, rendering him mute. Instead, Hauber portrays him incessantly spitting, moaning, and "making a bird sound" (Haubner 2017, p. 178). Lizzie and Jack take care of him as they take care of a baby, changing his diaper and feeding him through a tube. They in effect become the parents of a geriatric baby. The portrayal of the Zen teacher here thus differs immensely from the influential Zen ideology of the teacher as the dazhangfu or, as Haubner translates this term, "the grand old man of Zen" (Haubner 2017, p. 168). ${ }^{5}$ It also differs from Sasaki's own phallic personality, who "abuses the women and emasculates the men" in the community (Haubner 2017, p. 136). Like Jack, in Single White Monk Sasaki has become completely dependent on others. His body has also become feminized as his penis is "buried mangina style in a flab of old man crotch fat like the largely useless organ it was supposed to be at his age" (Haubner 2017, p. 130). When an exhausted Jack causes an accident caring for Sasaki, he panics into thinking that "I castrated my Zen master" (Haubner 2017, p. 162). The body of his teacher shows Jack that nothing is stable, and that opposites, such as baby and old man, male and female, intersect.

At the end of Single White Monk, Jack's accepts his feminine side and the shadow side of his master. But this does not happen within the institutional context of the Zen monastery, nor does he will himself into doing so. In an afterword that directly follows the long chapter that describes the scandal and its aftermath, Jack considers cutting this chapter because so many of his monastic friends find it objectionable. A man called Dutch, who otherwise is highly critical of Sasaki, protests the chapter "desecrates the Dharma" (Haubner 2017, p. 200). We have already seen how Haubner's gay mentor (who trained with Sasaki) feels Haubner is taking out his deep misogyny by projecting it on his teacher. This leads him to also object against the chapter (Haubner 2017, p. 136). Trying to find a solution to this dilemma, Jack takes part in a shamanistic session powered by the hallucinogenic drug ayahuasca. After imbibing it, the drug takes control of Jack: "Ayahuasca is no longer in me. I am in ayahuasca" (Haubner 2017, p. 203). This becomes "an experience of hell" that leads to intense vomiting (Haubner 2017, p. 203). His body acts on its own: "Of their own volition my teeth star ripping out of my skull ... It is like a waterfall into the bucket, but no hint of a human being, no moan or gasp, just this blasting spray of fluid like a fire hose and then silence" (Haubner 2017, p. 204). The morning after, Jack is told by the shaman's female assistant:

I feel you were very tight at the monastery. I feel you worry about what the others think and you become tight and try harder and harder but don't feel. It goes back to your father. And his father. And his father. And you brought your father and his father and his father to the monastery with you. And you tried to be man-monk. But you stopped feeling. Now you feel again. The plant, the Mother [Ayahuasca] says, 'Now you feel again.' (Haubner 2017, p. 205)

The symbolism here is quite obvious: encountering the "Mother," who put him completely at the mercy of his bodily needs, has healed Jack's patriarchal past, and has dissolved the

\footnotetext{
5 For more on the term dazhangfu and its usage in the Zen tradition, see studies by Beata Grant and Miriam Levering (Levering 1992; Grant 2008).
} 
illusion of the buffered self. Jack now finally sees what "Zen has been showing me all along. That I'm a nobody. I'm free of a fixed, solid self. Attach to some idea that you need to be, or are, this or that, and suffering begins" (Haubner 2017, p. 205). Instead of writing a new chapter to replace the "scandal chapter," Jack resigns from Sasaki's temple and admits his need for "company" (Haubner 2017, p. 36).

\section{Conclusions: A Postmodern Ascetic?}

In many ways, the evolution that Jack undergoes in Haubner's memoirs is an ascetic one. He gains insight into the interconnectedness of his own life with the rest of the universe, which describes the modern interpretation of the Buddhist doctrine of interdependent origination (McMahan 2008, pp. 149-82). Paired with this insight is a suspension of conventional boundaries, which in the popular understanding of the Mahayana Buddhist thinker Nagarjuna would mean he sees every being as ultimately empty while at the same time remaining aware that provisionally, distinctions between things exist. Although Jack thus is ascetic in that his self becomes shaped to fit the modern Zen tradition, erasing his individuality in the process, this is not something Jack accomplishes through his own volition. Instead, his penetrated, feminized, sick, pregnant, and drugged body leads him towards these insights.

In the final chapter of his book, which some reviewers have called the weakest (Pomplun 2007; Olson 2008), Flood argues that the "postmodern critique of modernity has allowed the reappropriation of the ascetic self as a legitimate form of subjectivity within the bounds of reconfigured traditions" (Flood 2005, p. 236). Flood sees the ascetic self as playing a role in resolving the tension between modernity and tradition. He points to the Islamic ideal of the religious martyr (belonging to such organizations as Al-Qaeda or the Islamic State) as one (politicized) example of such postmodern asceticism, where one attempts to return to a tradition that has already been deeply reshaped by modern discourses such as secularity (Flood 2005, pp. 252-54). Jack fits this framework in that his self becomes shaped according to modern Buddhist ideals. But a crucial difference is that Haubner's books decenter the volition of the ascetic, locating agency in the body.

Glucklich's framework also offers a partial understanding of Jack's journey towards awakening. The end of the "Expiration Date" chapter, where Jack's excruciating pain subsides and he feels new life inside of him, can be read as a return to a premodern, religious understanding of pain as "medicine, a test, a rite of passage, or an alchemical agent of inner transformation" (Glucklich 2003, p. 210). However, Glucklich does not allow us to understand how Haubner's other bodily functions and drives, mainly his sexual desire, play a role in his awakening.

While Flood and Glucklich are thus both valuable in understanding Jack's spiritual journey, they also leave something out. That "something" can be articulated through Donna Haraway's influential discussion of the postmodern body as a "cyborg." Examining scientific discussions of how the human body's cells collaborate, Haraway concludes: "The individual is a constrained accident, not the highest fruit of earth's labors" (Haraway 1991, p. 220). The mechanisms that sustain it are "a chief witness to the irreducible vulnerability, multiplicity, and contingency of every construct of individuality" (Haraway 1991, p. 220). Similarly, Sidonie Smith concludes that in postmodern autobiographical works, the body is both the basis of subjectivity and a means to destabilize the "universal" subject of modernity which imagines that it is somehow separate from the body it exists within (Smith 1994). Haubner takes such ideas of the postmodern body as something that undermines modern subjectivity and adjusts these notions to a Zen Buddhist context. Jack can therefore, I propose, be best understood as a postmodern ascetic.

Funding: This research received no external funding.

Conflicts of Interest: The author declares no conflict of interest. 


\section{References}

Flood, Gavin. 2005. The Ascetic Self: Subjectivity, Memory and Tradition. New York: Cambridge University Press.

Gleig, Ann. 2019. American Dharma: Buddhism beyond Modernity. New Haven: Yale University Press.

Glucklich, Ariel. 2003. Sacred Pain: Hurting the Body for the Sake of the Soul. New York: Oxford University Press.

Goldberg, Natalie. 2004. The Great Failure: A Bartender, a Monk, and My Unlikely Path to Truth. San Francisco: Harper.

Grant, Beata. 2008. Da Zhangfu: The Gendered Rhetoric of Heroism and Equality in Seventeenth-Century Chan Buddhist Discourse Records. Nan Nü 10: 177-211. [CrossRef]

Greenwood, Gesshin Claire. 2018. Bow First, Ask Questions Later: Ordination, Love, and Monastic Zen in Japan. Somerville: Wisdom Publications.

Haraway, Donna Jeanne. 1991. Simians, Cyborgs, and Women: The Reinvention of Nature. London: Free Association Books.

Haubner, Shozan Jack. 2013. Zen Confidential: Confessions of a Wayward Monk, 1st ed. Boston: Shambhala.

Haubner, Shozan Jack. 2017. Single White Monk: Tales of Death, Failure, and Bad Sex (Although Not Necessarily in That Order), 1st ed. Boulder: Shambhala.

Haubner, Shozan Jack. 2020. Those People. Available online: https://shozanjhaubner.medium.com/those-people-20c4a96261cf (accessed on 6 November 2020).

Levering, Miriam L. 1992. Lin-Chi (Rinzai) Ch'an and Gender: The Rhetoric of Equality and the Rhetoric of Heroism. In Buddhism, Sexuality, and Gender. Edited by José Ignacio Cabezón. Albany: State University of New York Press, pp. 137-56.

Matthiessen, Peter. 1985. Nine-Headed Dragon River: Zen Journals 1969-1982. Boston: Shambhala.

McMahan, David L. 2008. The Making of Buddhist Modernism. New York: Oxford University Press.

Olson, Carl. 2008. Review of Flood, Gavin. The Ascetic Self: Subjectivity, Memory and Tradition. The Journal of Religion 88: 116-18. [CrossRef]

Pomplun, Trent. 2007. Review of The Ascetic Self: Subjectivity, Memory, and Tradition by Gavin Flood. Modern Theology 23: 307-9. [CrossRef]

Sasaki, Ruth Fuller. 2009. The Record of Linji. Edited by Thomas Yūhō Kirchner. Honolulu: University of Hawai'i Press.

Schireson, Grace. 2019. Naked in the Zendo: Stories of Uptight Zen, Wild-Ass Zen, and Enlightenment Wherever You Are. Boulder: Shambhala.

Smith, Sidonie. 1994. Identity's Body. In Autobiography \& Postmodernism. Edited by Kathleen Ashley, Leigh Gilmore and Gerald Peters. Amherst: University of Massachusetts Press.

Taylor, Charles. 2007. A Secular Age, 1st ed. Cambridge: The Belknap Press of Harvard University Press.

Vitello, Paul. 2017. Joshu Sasaki, 107, Tainted Zen Master. The New York Times. Available online: https://www.nytimes.com/2014/08/ 05/us/joshu-sasaki-a-zen-master-tarnished-by-abuse-claims-dies-at-107.html (accessed on 20 December 2017).

Wilson, Liz. 1996. Charming Cadavers: Horrific Figurations of the Feminine in Indian Buddhist Hagiographic Literature. Chicago: University of Chicago Press. 